\title{
KONSTANTYNOPOL JAKO „IППО ZMAGAŃ ARMII Z FAKCJONISTAMI BUNTOWNIKAMI I MIESZKAŃCAMI W CZASIE POWSTANIA NIKA W 532 ROKU
}

\begin{abstract}
Streszczenie. Artykuł przedstawia działania armii cesarskiej w czasie powstania Nika. Analizie zostały poddane fragmenty dotyczące dni 14, 17 i 18 stycznia 532 r. Pierwsze potwierdzone źródłowo użycie armii datuje się na 14 stycznia. Walki z buntownikami pod wodzą Belizariusza toczyły się do wieczora i nie przyniosły oczekiwanych rezultatów, powstanie nadal trwało i powodowało coraz więcej zniszczeń. W dniu 17 stycznia przybyły posiłki z okolicznych miast. Jak pokazują badania, samo pojawienie się większej armii w mieście wywołało eskalację napięcia i paradoksalnie stało się powodem do natychmiastowego jej użycia. Użycie większej siły nie zakończyło powstania i doprowadziło do największych zniszczeń od początku jego wybuchu. Najemnicy pod dowództwem Belizariusza i Mundusa okazali się fundamentem podtrzymującym władzę Justyniana Wielkiego w styczniu 532 r., ponieważ, w odróżnieniu od oddziałów gwardii cesarskiej, okazali się lojalni wobec swoich przełożonych oraz cesarza. Źródłem przekazującym najwięcej informacji o działaniach wojennych w czasie powstania Nika jest Chronicon Paschale, która uszczegóławia relację m.in. Jana Malalasa. Przekaz Prokopiusza z Cezarei wydaje się użyteczny jedynie przy interpretacji działań z 18 stycznia.
\end{abstract}

Słowa kluczowe: powstanie Nika, fakcje cyrkowe, wojna, armia, Belizariusz

Urzadzanie szpetnych widowisk to robienie widowiska z samego siebie ${ }^{1}$.

Grzegorz z Nazjanzu

Tytuł niniejszego artykułu to swoisty zabieg retoryczny, natomiast nieprzypadkowy cytat na początku spełnia dwie funkcje. Po pierwsze, odnosi się do autora najwcześniejszej wzmianki na temat istnienia demów

${ }^{1}$ Grzegorz z Nazjanzu, Epistulae - Saint Grégoire de Nazianze, Lettres, t. 2, ed.

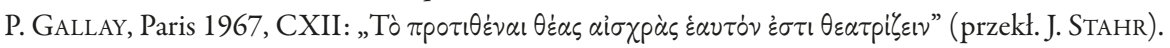


w Konstantynopolu² . Po drugie, w dość nietuzinkowy sposób łączy przedmiot rozważań z miejscem ${ }^{3}$, prowodyrami (fakcjoniści) oraz momentem wybuchu zamieszek (igrzyska na Hipodromie w Idy).

Należy na wstępie zaznaczyć, że w historiografii anglosaskiej zostały już przedstawione najważniejsze etapy przebiegu powstania Nika, co powoduje, że niemal ustała dyskusja na ten temat ${ }^{4}$. Poza tym nie posiadamy pełnego, pewnego stanu wiedzy o budynkach, o których mowa w źródłach, co sprawia, że w obliczu rozbieżności nie jesteśmy w stanie wypracować całkowitego, spójnego obrazu wydarzeń. Samo powstanie trwało 6 dni - od wtorku do niedzieli 13-18 stycznia - i pochłonęło co najmniej 35 tys. istnień ludzkich5'. Niniejszy artykuł ma na celu przedstawienie wątków związanych z wojskowością i działaniem armii (głównie 14, 17 i 18 stycznia). Autor będzie starał się pokazać, że nawet niewielka ilość materiału źródłowego pozwala wysnuć ciekawe wnioski prowadzące do drobnych, lecz wartościowych konkluzji. Wielokrotnie w opracowaniu umieszczono tłumaczenia własne tekstów źródłowych, które to tłumaczenia nie są rzecz jasna idealne, ale obrazują wkład pracy autora przy próbie rzetelnego przedstawienia tematu.

W V w., kiedy Cesarstwo Zachodniorzymskie pogrążyło się w chaosie i miało ostatecznie upaść pod naporem barbarzyńców, na Wschodzie na wielu płaszczyznach zaczęto przeprowadzać niezbędne reformy. W wyniku przezwyciężenia kryzysu wewnętrznego w pierwszej połowie VI w. Cesarstwo Wschodniorzymskie podjęło pod rządami Justyniana doniosłą próbę odzyskania utraconych na zachodzie terytoriów. Czasy panowania Justyniana I (527-562) miały stać się pierwszym krokiem do zrealizowania bardzo żywej wówczas idei renovatio imperii Romanorum, początkiem nowej ery. Poza działaniami wojennymi doszło również do kodyfikacji prawa rzymskiego, pewnych reform administracyjnych (zaczęto odchodzić

${ }^{2}$ T. WOLIŃSKA, Kibice i nie tylko, czyli konstantynopolitańscy fakcjoniści, [w:] Konstantynopol - Nowy Rzym. Miasto i ludzie w okresie wczesnobizantyńskim, red. M.J. LEszKA, T. WolińsKA, Warszawa 2011, s. 226-227.

3 Widowiska dzielimy na trzy główne kategorie ze względu na miejsce, w jakim się odbywają: sceniczne (teatralne), amfiteatralne i cyrkowe. Oczywiście igrzyska organizowane na Hipodromie zaliczają się do tej ostatniej kategorii, z małą „sceniczną domieszką” w przerwach między wyścigami.

4 Większość faktów ustalił J.B. BurY, The Nika Riot, ,The Journal of Hellenic Studies” 1997, t. 17, s. 92-119; zaktualizował G. GreATREX, The Nika Riot: A Reppraisal, „The Journal of Hellenic Studies” 1997, t. 117, s. 60-86; połączył z pozostałymi informacjami w monografii, tworząc książkę syntezę o fakcjach A. Cameron, Circus Factions: Blues and Green at Rome and Byzantium, Oxford 1976, s. 271-297, zwłaszcza s. 279-280.

5 Szczegółowe kalendarium powstania vide: G. GREATREX, op. cit., s. 82; J.B. BURY, op. cit., s. 118-119. 
od rozgraniczenia władzy cywilnej i wojskowej w prowincjach) oraz rozprawy z pogaństwem (zamknięcie Akademii Platońskiej). Ponadto państwo borykało się ze sporami religijnymi wewnątrz samego Kościoła. Między ortodoksami i monofizytami nieustannie dochodziło do eskalacji napięć, które cesarz starał się w autokratyczny sposób łagodzić (uważał się przy tym wręcz za głowę Kościoła) ${ }^{6}$.

Dla Justyniana wojna była jedynie narzędziem politycznym ${ }^{7}$, wolał „dowodzić” ze swojego pałacu i w praktyce miał niewielką styczność z polem bitwy. Potrafil jednak dobrze dobierać ludzi do zlecanych zadań, a co za tym idzie - dysponował kompetentną i lojalną, jak się miało okazać, kadrą dowódczą. Belizariusz jest przez wielu uważany za najlepszego dowódcę wczesnego Cesarstwa, a przez niektórych (pod czym i ja się podpisuję) za najlepszego dowódcę w historii całego Bizancjum. Nie można wszak pomijać tak wybitnych osobistości jak Narses, Germanos czy Mundus, których sukcesy zostały w pewnym stopniu przykryte przez wielki cień Belizariusza.

Hugh Elton twierdzi, że owa lojalność żołnierzy (w tym dowódców) wynikała z poczucia oddania dla władcy i Rzymu, a na poparcie tej tezy przywołuje Prokopiusza ${ }^{8}$. Nie zgadzam się z tą opinią. Zapewne nie były to dla wojskowych obojętne kwestie, ale należy zw rócić tutaj uwagę na coś jeszcze. Kariera wodzów była ściśle związana z utrzymaniem się na tronie władcy, któremu zawdzięczali zdobyte zaszczyty. Sam Belizariusz został przecież zauważony i wypromowany przez Justyna i Justyniana. W ten sposób łączyły się interesy władcy i jego ludzi - wraz ze wzrostem znaczenia Justyniana rósł prestiż jego kadry, a z jego spadkiem istniało ryzyko utraty intratnej pozycji.

Od późnego antyku (IV w.) armia rzymska (wschodnio- i zachodniorzymska) opierała się na barbarzyńskich rekrutach, którzy brali czynny udział w działaniach wojennych na wszystkich frontach (również pod dowództwem własnych wodzów). W wyniku tego uzależnienia już w V w. na Wschodzie doszło do likwidacji obcych, na swój sposób niezależnych regimentów i zaczęto włączać żołnierzy, oddziały w struktury armii rzymskiej९. Trudności

${ }^{6}$ H. Alivisatos, Die Kirchliche Gesetzgebung des Kaisers Justinian I, Berlin 1913.

${ }^{7}$ H. Elton, Army and Battle in the Age of Justinian (527-65), [w:] A Companion to the Roman Army, ed. P. ERDKAMP, Oxford 2007, s. 534.

8 Vide: ibidem, s. 535.

${ }^{9} \mathrm{Na}$ Zachodzie również starano się to robić, chociaż z marnym skutkiem, $c f$ : B.S. BACHRACH, Merovingian Mercenaries and Paid Soldiers in Imperial Perspective, [w:] Mercenaries and Paid Men: The Mercenary Identity in the Middle Ages, ed. J. FranCE, Leiden-Boston 2008, s. 167-192. 
z pozyskaniem rekruta wynikały przede wszystkim z niedostatecznych zasobów ludzkich, które pochłaniał obowiązek utrzymywania stałych garnizonów na granicy (limitanei) i mobilnej, również stałej, armii zawodowej (comitatenses). Dla przykładu w 559 r. armia rzymska liczyła 150 tys. ludzi ${ }^{10}$. $Z$ tego powodu w późnym antyku głównym źródłem rekruta były obeznane z wojaczką ludy barbarzyńskie.

Poza barbarzyńskimi żołnierzami chętnie werbowano Izaurów, Illirów, mieszkańców Tracji oraz Armenii ${ }^{11}$. Etniczna klasyfikacja składu armii za czasów Justyniana budzi tyle kontrowersji, że powstały dwie szkoły prezentujące $\mathrm{w}$ tych kwestiach odmienne wnioski ${ }^{12}$. Dwie rzeczy są jednak pewne: niedostateczna liczba rekrutów i elastyczność sytuacyjna armii rzymskiej. Pierwszy wniosek miał jeszcze inne podłoże - problemy demograficzne będące skutkiem epidemii z $541 \mathrm{r}$. Drugi natomiast stanowi przyjęcie status quo w bardzo rozbudowanym, specjalistycznym dyskursie akademickim między ekspertami obu obozów. Przez elastyczność - za Johnem L. Teallem - rozumie się działania uzależnione od sytuacji, otoczenia i możliwości. Z reguły starano się ograniczać werbunek w trakcie kampanii lub wysyłać obce regimenty z dala od „macierzystego" frontu. Jako przykład można podać pięć regimentów Vandali Iustiniani lub Gotów wysłanych na front wschodni ${ }^{13}$. Oczywiście nie można było uniknąć sytuacji, w której armia będzie uzupełniana na terytorium wroga. W tej kwestii wszystko zależało od wodza, toteż nie da się w pełni rozstrzygnąć kwestii demograficznej armii okresu panowania Justyniana.

Bardziej przekonuje mnie jednak argumentacja zwolenników „barbarzyńskiej przewagi liczebnej” w armii rzymskiej pierwszej połowy VI w. Wynika to ze styczności z tematyką powstania Nika (źródłami) i danych liczbowych określających np. proporcje barbarzyńskich foederati w kampanii wandalskiej Belizariusza (9:4 dla foederati) $)^{14}$.

10 W. Treadgold, Byzantium and Its Army, 284-1081, Stanford 1995, s. 74.

${ }^{11}$ H. Elton, op. cit., s. 535; vide: M. WhITBY, Recruitment in Roman Armies from Justinian to Heraclius (ca. 565-615), [w:] Late Antiquity on the Eve of Islam, ed. A. CAMERON, London 2013, s. 277-341.

12 Vide: J.L. Teall, The Barbarians in Justinian's Armies, „Speculum” 1965, t. 40, nr 2, Chicago, s. 294-322.

${ }_{13}$ H. Elton, op. cit., s. 533-536.

${ }_{14}$ Vide: R. Remondon, Soldats de Byzance d'après un papyrus trouvé à Edfou, Recherches de Papyrologie, t. 1, Paris 1961, s. 46. 
Według Bernarda S. Bachracha jedynie dwie formacje wojskowe tamtego okresu z pełnym przekonaniem można określić jako najemne: foederat i i bucellarii (bucelariuszy różnie określano), a co do reszty nie ma pewności ${ }^{15}$. Prowadzono wiele dyskusji nad terminologią dotyczącą najemników, próbując określić znaczenie słów conducticius i miles mercenarius na podstawie kontekstu źródłowego, jednak autorzy źródeł niechętnie ich opisywali ${ }^{16}$. Przyporządkowanie oddziałom foederati funkcji oddziałów najemnych dość mocno zakorzeniło się w literaturze anglosaskiej, dlatego charakter tej pracy nie narzuca głębszej analizy poprawności takiego stanu rzeczy (a nawet oznacza jego akceptację) $)^{17}$. Żołnierzy do tych oddziałów werbowano z barbarzyńskich ochotników (zromanizowanych lub całkowicie obcych). Bucellarii natomiast budzą większe zainteresowanie przez wzgląd na ich szczególne znaczenie w otoczeniu wodza (gwardia przyboczna). Ten termin wywodzi się od bucellum znaczącego suchary wojskowe, a więc stąd prosty wniosek, że oni również służyli „dla chleba”. Co ciekawe, Timo Stickler stosuje dość proste określenie na bucelariuszy, nazywając ich prywatnymi armiami składającymi się z barbarzyńskich najemników ${ }^{18}$. Wolf Liebeschuetz dodaje natomiast, że przysięgali lojalność zarówno cesarzowi, jak i dowódcy i byli częściowo utrzymywani na jego koszt, co tylko „częściowo” pokrywa się z określeniem ich jako żołnierzy prywatnych armii ${ }^{19}$.

W konsekwencji powyższych ustaleń metodologicznych w dalszej części tekstu zostały poczynione uproszczenia, stosowane również w literaturze anglosaskiej. Pod pojęciem „najemników” kryją się bliżej nieokreślone formacje

15 B.S. BACHRACH, op. cit., s. 176.

16 Ibidem, s. 174; cf: J. Haldon, Warfare, State and Society in Byzantine World, 565-1204, London 1999, s. 91-96, 125-126, 262-264.

17 T. Stickler, The Foederati, [w:] A Companion to the Roman Army, ed. P. ERdKAmP, Oxford 2007, s. 497-499; cf: M.J. NICASIE, Twilight of Empire: The Roman Army from the Reign of Diocletian until the Battle of Adrianople, Amsterdam 1998, s. 84: "probably from about the reign of Diocletian onwards, voluntary recruitment was supplemented by the absorption into the army of the sons of veterans, who were legally bound to enter their fathers' profession, and by a provincial levy in the form of a tax which obliged landholders to provide for the army a number of recruits based on the size of their estates. Thirdly, at first only comparatively rarely but towards the end of the fourth century more regularly, the army was strengthened by hiring complete barbarian mercenary regiments under their own officers. These units were known as foederati, since their relation with the empire was regulated by a foedus, a treaty".

18 T. STICKLER, op. cit., s. 498.

19 W. Liebeschuetz, Warlords and Landlords, [w:] A Companion to the Roman Army, ed. P. ERDKAMP, Oxford 2007, s. 483. 
żołnierzy kontraktowych, składających się głównie z barbarzyńców (zromanizowanych i niezrozmanizowanych). Brak możliwości precyzyjnego określenia typu oddziału wynika z braku dostatecznych informacji źródłowych, które posługują się określeniem „żołnierz”. W wypadku Gotów i Herulów nazywanych „żołnierzami” (oi $\sigma \tau p \alpha \tau i \tilde{\omega} \tau \alpha \iota)$ możemy się domyślić, że byli to po prostu najemnicy barbarzyńscy. Ich hasłem było: „Zwyciężaj”, aby nie zostali zinfiltrowani przez żołnierzy lub excubitores ${ }^{20}$.

Jan Malalas podaje informację, że hasło „Nika” wymyślono w celu przeciwdziałania infiltracji ze strony żołnierzy (ogólne określenie) lub excubitores (konkretna formacja gwardii pałacowej powołana w V w.). Jak widać, etymologia tego hasła jest swoistą ciekawostką, często pomijaną w literaturze, i dostarcza dodatkowych informacji o prawdopodobnych infiltracyjnych działaniach podejmowanych przez gwardię pałacową. Czy faktycznie wykrzykiwano to hasło, czy raczej funkcjonowało ono wśród zaufanych członków demów uczestniczących w powstaniu, do końca się nie dowiemy. „I wyszedł Belizariusz wraz z wielką liczbą (oddziałem) Gotów. Spotykając zwarli się (w dom. z fakcjonistami) i zabili wielu z nich"21.

Jak informuje fragment Kroniki Malalasa, do pierwszych skoordynowanych starć z buntownikami przeprowadzonych pod dowództwem Belizariusza doszło tuż po dymisji urzędników 14 stycznia. Taki wniosek podyktowany jest narracją źródłową, która sugeruje dość krótki odstęp między tymi wydarzeniami. Użyte w tekście sformułowanie dotyczy jedynie pochodzenia żołnierzy, co pozwala zaklasyfikować ich jako najemników. O wiele trudniejsze jest określenie, czy byli to foederati goccy, czy gwardia przyboczna Belizariusza (bucellarii). Bardziej skłaniam się ku temu, że Belizariusz dysponował wówczas jedynie gwardią przyboczną. Po porażce pod Callinicum został oskarżony o tchórzostwo i wezwany do stolicy, więc nie pełnił wówczas żadnej ważniejszej funkcji. Ponadto Prokopiusz (skrzętnie milczący na temat szczegółowych powodów wezwania i oskarżeń) podaje, że Belizariusz przybył do Konstantynopola ze „świtą i silnym oddziałem bucellariuszy" (vide: s. 10). Należy więc przyjąć, że wspomniani w tekście Goci należeli do formacji bucelariuszy, a nie foederati.

${ }^{20}$ Ioannis Malalae chronographia, ed. L. DindorfiUs, [w:] Corpus scriptorum historiae Byzantinae,

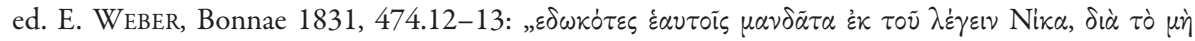

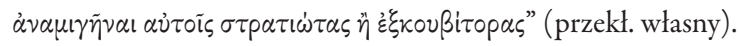

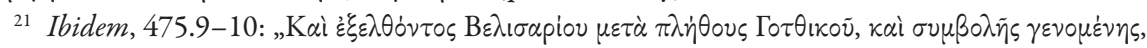

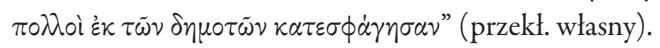


Drugie źródło zdaje się potwierdzać wcześniejszą relację, informując dodatkowo za pomocą słowa $\dot{\varepsilon} \sigma \pi \dot{\varepsilon} p \alpha$ ('wieczór'), do kiedy trwały starcia. Dzień 14 stycznia obfitował w wydarzenia: kontynuowano igrzyska, podpalono trybuny, zdymisjonowano urzędników i do wieczora trwały starcia wojska z buntownikami ${ }^{22}$.Takakolejnośćwydarzeń sugeruje,że pomiędzy udaną, wymuszoną dymisją a walką doszło do wyraźnych, groźnych działań ze strony fakcjonistów.

Niepotwierdzona informacja, podająca powód posłania wojska, pojawia się

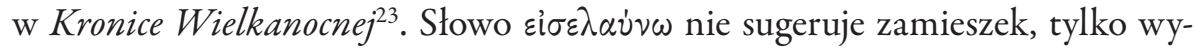
daje się użyte w kontekście tryumfu tłumu po osiągnięciu celu - dymisji Jana z Kapadocji, Tryboniana i Eudajmona. Tutaj należy postawić ważne pytanie: Czy faktycznie było to tak pokojowe działanie? Gdyby był to zwykły akt radości i poparcia dla władzy Justyniana, to nie musiałby on wysyłać wojska w celu rozbicia tłumu ${ }^{24}$. Słuszna wydaje się tutaj koncepcja o kontynuowaniu przez lud wszelkiego rodzaju grabieży w przypływie euforii z powodu wymuszonych ustępstw ze strony cesarza.

Następne dni są w niewielkim stopniu udokumentowane źródłowo (szczególnie pod kątem walk), więc kolejnym analizowanym w niniejszej pracy działaniem wojska są wydarzenia z 17 stycznia 532 r. Najwięcej szczegółów dotyczących tego dnia można znaleźć w Kronice Wielkanocnej, która przekazuje dość cenne informacje:

(1) W sobotę, 17 dnia tego samego miesiąca Audynajos (stycznia), do walki z demami dołączyli żołnierze, którzy przybyli z Hebdomonu, Regium, Athyry i Kalabrii (fort). (Dołączyli w domyśle) po tym, jak fakcjoniści zaczęli mordować ludzi ${ }^{25}$. (2) i wrzucali ich do morza jak ubytki (odchody), podobnie czynili z kobietami ${ }^{26}$,

22 Chronicon Paschale, ed. L. Dindorfius, [w:] Corpus scriptorum historiae Byzantinae, t. 1, ed.

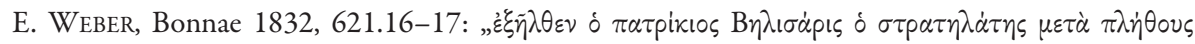

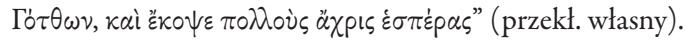

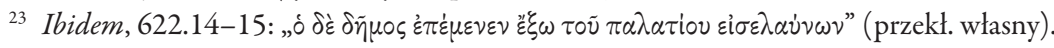

${ }^{24}$ Pojawiają się tutaj opinie, że owe żądania z 14 stycznia były inspirowane przez kręgi arystokratyczne, vide: C. GIZEWSKI, Zur Normativität und Struktur der Verfassungsverbältinisse in der späteren römischen Kaiserzeit, München 1988, s. 164; H. LEPPIN, Justinian. Das christliche Experiment, Stuttgart 2011, s. 145.

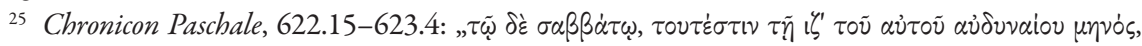

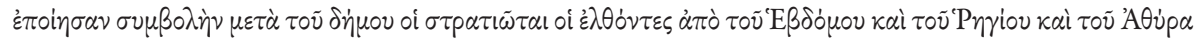

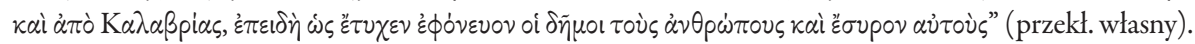

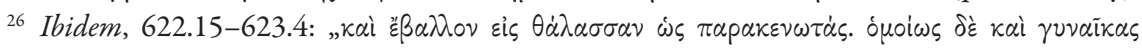
غ̇фóvยvov" (przekł. własny). 
(3) i wielu fakcjonistów zginęło (w wyniku walki z armią). Kiedy tłum ujrzał, że przegrywa, wycofał się do Oktagonu, który znajduje się pomiędzy Bazyliką (? ${ }^{27}$ a publicznym portykiem Regii ${ }^{28}$. (4) Żołnierze ujrzeli, że nie są na tyle silni, aby tam się przedostać i sami rzucili ogień nad tłumem i podpalili Oktagon (chrzcielnica, kaplica? ${ }^{29}$. (5) (...) i fakcjoniści uciekłszy stamtąd podłożyli ogień pod Liburnonem i pod Magnaurą ${ }^{30}$, lecz po powstaniu wielkiego zbiegowiska został natychmiast ugaszony ${ }^{31}$.

Kronika informuje, że armia przybyła 17 stycznia (1), co sugeruje, że musiała zostać wezwana kilka dni wcześniej (co najmniej 14 stycznia) ${ }^{32}$. Nie posiadamy informacji na temat konkretnych kontyngentów wchodzących w jej skład. Biorąc pod uwagę wspomniane na początku artykułu zróżnicowanie armii rzymskiej, należy po prostu zdać się na uproszczone nazewnictwo.

Działania cesarza wydają się sugerować, że jeszcze 13 i nawet 14 stycznia (rano!) 532 r. nie spodziewał się on takiej eskalacji przemocy i zniszczeń ${ }^{33}$. Biorąc pod uwage dystans dzielący wspomniane miejsca stacjonowania armii (kilkanaście kilometrów), żołnierze mogli rzeczywiście przybyć już 17 stycznia. Niewystarczająca liczba ludzi gotowych do walki z buntownikami mogła być również powodem dość pasywnej postawy cesarza w dniach $15-16$ stycznia.

${ }^{27}$ Należy być tutaj ostrożniejszym, używając określenia: „Basilica of the Skindressers” (proszących o łaskę), cf:: Chronicon Paschale 284-628 AD, t. 7, przekł. M. Whiтвy, M. Whiтвy, Liverpool 1989, s. 120.

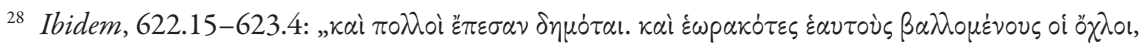

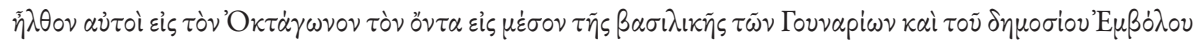

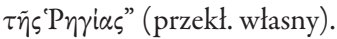

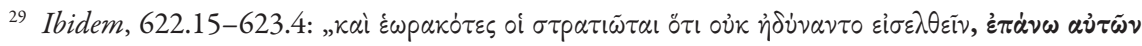

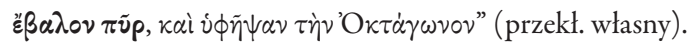

${ }^{30}$ Pałace Magnaura i Liburnon mieściły się prawdopodobnie gdzieś we wschodniej części Augusteum, vide: G. GreateX, op. cit., s. 86. Mango zestawia Magnaurę z budynkiem Senatu we wschodniej części Augusteum, a Liburnon z marmurowym posągiem okrętu - liburny, vide: C.A. Mango, The Brazen House: A study of the vestibule of the imperial palace of Constantinople, Kopenhaga 1959, s. 57-58.

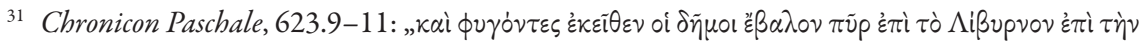

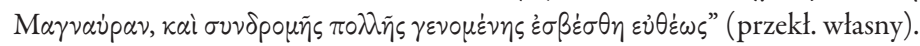

32 G. Greatrex stawia nawet tezę, że Justynian musiał posłać po wojsko 16 stycznia: „No imperial response was forthcoming, but Justinian must by this stage have ordered troops stationed in Thrace to march to the capital. They arrived the following day and proceeded to engage the rioters", vide: G. GREATREX, op. cit., s. 75 .

${ }^{33}$ Ibidem, s. 70-71. 
Nie do końca jasne są tutaj informacje dotyczące początku walk z 17 stycznia. Z narracji źródłowej (Kroniki Wielkanocnej) rysuje się obraz „buntowników, nie zbrodniarzy"34, do 17 stycznia walczących jedynie z władzami miasta i cesarzem oraz podpalających budynki. O zabijaniu mieszkańców, i to w niesamowicie brutalny sposób, mowa w źródle dopiero po przybyciu armii (2). Sugeruje to być może jakieś powiązanie, ponieważ natychmiastowe użycie wojska do zaprowadzenia porządku w mieście zostało wytłumaczone morderstwami popełnianymi przez powstańców. Najprawdopodobniej źródło pomija wcześniejsze czyny, podkreślając tutaj polaryzację nastrojów po przybyciu armii. Więc był to nie tylko powód włączenia się armii do pacyfikacji miasta, ale też zarazem konsekwencja jej przybycia.

Gdy lepiej uzbrojeni i wyszkoleni żołnierze zaczęli wygrywać starcie oraz spychać tłum, ten okopał się w pobliżu Oktagonu (3). Bliżej nieznane są nam

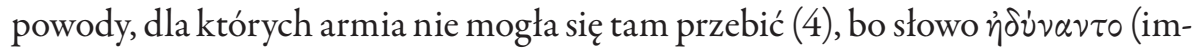

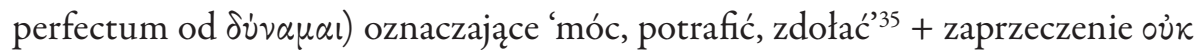
stanowi jedyną wzmiankę na ten temat. Faktem natomiast jest wniosek, który wysuwa również Geoffrey Greatrex, że użycie większej siły paradoksalnie doprowadziło do jeszcze większych zniszczeń w mieście w ciągu ostatnich dwóch dni (w porównaniu z 13-16 stycznia). Można przyjąć, że podłożenie ognia pod pałace Magnaura i Liburnon było swoistym odwetem za Oktagon (5).

Przechodząc wreszcie do analizy działań w ostatnich dniach, należy najpierw powiedzieć nieco o samych wodzach i ich wojsku (mowa oczywiście o Belizariuszu i Mundusie). Prokopiusz dostarcza nam cennych informacji dotyczących nie tyle liczb, co rodzaju wojska, a najbardziej jego pochodzenia:

Cesarz całą nadzieję pokładał w Belizariuszu i Mundusie. Pierwszy z nich, Belizariusz, powróciłświeżo z wojny z Persją i nie tylko przyprowadził ze sobą silną i godną uwagi świtę, lecz przede wszystkim miał silny oddział bucellariuszy, oficerów i szeregowych, zaprawionych w bojach i niebezpieczeństwach wojennych. Mundus zaś, mianowany dowódcą wojsk w Illiri, zupełnie przypadkowo przybył do Bizancjum wezwany w jakiejś sprawie, prowadząc ze sobą oddział barbarzyńskich Herulów ${ }^{36}$.

34 Oczywiście $\mathrm{w}$ innych źródłach autorzy wprost nazywają powstańców mordercami, vide: Prokopiusz z Cezarei, De bellis, ed. H. Jacobus, Procopii Caesariensis opera omnia, t. 1, pub. B.G. TEUBNER, Leipzig 1962, I, 24, 2-6.

35 Stownik grecko-polski, t. 1, red. Z. ABRAMOWiCzównA, Warszawa 1958, s. 606.

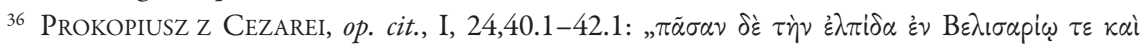

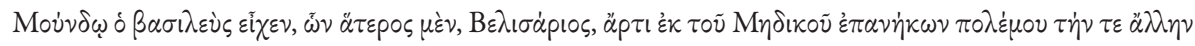


Goci zostali już omówieni przy analizie wydarzeń z 14 stycznia, jednak należy podkreślić, że z całą pewnością nie byli jedynymi weteranami przyprowadzonymi przez Belizariusza ${ }^{37}$. Drugi z dowódców - Mundus - dowodził

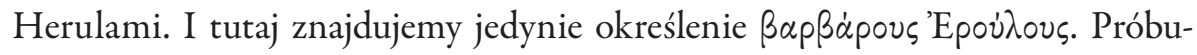
jąc określić, czy byli to foederati, czy bucellarii, musimy wziąć pod uwagę obie możliwości. Mundus sprawował w tamtym czasie funkcję magister militum per Illyricum, skupiał zatem w swoim ręku znaczną liczbę wojsk. Z racji swojego położenia Illiria była źródłem barbarzyńskiego, bitnego rekruta (Gepidowie, Goci i wreszcie Herulowie). Musiał więc kontraktować lokalnych barbarzyńców jako federatów, w tym Herulów. Ale Prokopiusz nie podaje dokładnego powodu przybycia Mundusa do stolicy. Mógł nie znać konkretnego powodu lub uznać, że nie jest to informacja warta uwagi. Jego narracja sugeruje jedno i drugie - zapewne chodziło o jakieś sprawy osobiste, o których nie wypadało pisać publicznie. Jeśli takie założenie okazałoby się prawdziwe, to można przyjąć, że przybył do Konstantynopola bardziej jako osoba prywatna. A co za tym idzie, musiał zabrać ze sobą raczej gwardię przyboczną, bucelariuszy, nie federatów. Jednak to tylko przypuszczenie, nie mamy na to żadnego potwierdzenia źródłowego. Zatem obaj wodzowie mieli do dyspozycji wiernych sobie najemników, w mniejszym stopniu również wiernych cesarzowi. Okazało się to dość kluczowe ostatniego dnia powstania, kiedy żołnierze pałacowi czekali na rozwój wypadków.

Dnia 18 stycznia rozegrało się dość dużo wydarzeń, szczególnie o charakterze politycznym. Jednak w niniejszej pracy celowo pomijane są tego rodzaju wątki. O zwycięstwie wojska tamtego dnia można powiedzieć, że było bezpośrednim skutkiem znakomitej intuicji Belizariusza lub też dziełem przypadku. Najbardziej wiarygodny przekaz można oczywiście znaleźć u Prokopiusza ${ }^{38}$ :

43. Mundus wyszedł z pałacu bramą nazwaną od krętego zejścia „ślimakiem”. 44. Belizariusz natomiast najpierw skierował się prosto do samego Hypacjusza i loży cesarskiej. Skoro dotarł do przylegającego budynku, gdzie od dawien dawna żołnierze

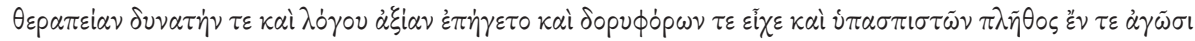

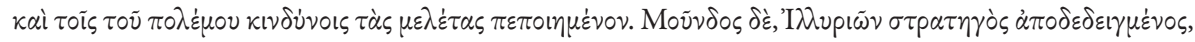

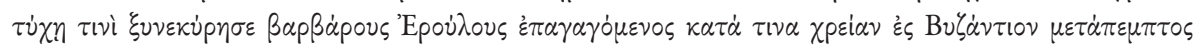

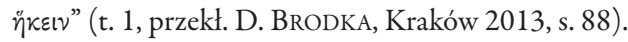

${ }^{37}$ Literatura bywa tutaj jeszcze ostrożniejsza, informując nie tyle o "Gotach Belizariusza”, co o „wojsku”, cf.: P. FilipCZAK, Bunt Nika (532 r.), [w:] Konstantynopol - Nowy Rzym... s. 330-332.

${ }^{38}$ Jak powszechnie wiadomo, Prokopiusz mimo dość nieprzychylnego stosunku do Justyniana (Historia Arcana) w swojej De bellis bardzo gloryfikuje Belizariusza.
} 
pełnili straż zawołał do nich, rozkazując jak najszybciej otworzyć drzwi, aby mógł ruszyć przeciw tyranowi. 45. Ponieważ jednak żołnierze postanowili nie wspierać żadnej z stron, dopóki któraś z nich nie zdobędzie zdecydowanej przewagi, udawali, że niczego nie słyszą, i tak go zbyli. 46. Belizariusz wycofał się więc z powrotem do cesarza i stwierdził, że ich akcja się nie powiodła. 47. Zbuntowali się bowiem żołnierze, którzy stali na straży pałacu. Cesarz rozkazał mu wobec tego udać się do tak zwanej Spiżowej Bramy i tamtejszych propylejów. 48. Belizariusz, brnąc przez ruiny i na wpół spalone budynki, z trudem, nie bez niebezpieczeństwa i wielkiego wysiłku dotarł do stadionu. 49. Skoro znalazł się przy Błękitnej Kolumnadzie, która jest na prawo od loży cesarskiej, postanowił najpierw ruszyć na samego Hypacjusza. Skoro jednak były tam małe drzwi, które były zamknięte i strzeżone od środka przez żołnierzy Hypacjusza, obawiał się, że w przypadku walki w ciasnym przejściu może zostać zaatakowany przez lud. W takiej sytuacji cały jego oddział zostałby łatwo zniszczony, a zwycięski tłum bez większego trudu mógłby ruszyć na cesarza. 50. Belizariusz doszedł zatem do wniosku, że musi zaatakować lud, który zgromadził się na Hipodromie. Były tam nieprzebrane tłumy, tłoczące się bez żadnego porządku. Wydobywszy miecz z pochwy, kazał reszcie uczynić to samo i z okrzykiem ruszył do szarży na tłum. 51. Lud, ściśnięty i kłębiący się bez porządku, rzucił się do ucieczki, skoro tylko dostrzegł opancerzonych żołnierzy, cieszących się wielką sławą z powodu męstwa i doświadczenia wojennego, siekących mieczami bez żadnej litości. 52. Gdy podniósł się, co jest rzeczą naturalną, wielki wrzask, Mundus, człowiek mężny i energiczny, chciał przyłączyć się do walki, jednak nie był pewny, jak postąpić w obecnej sytuacji. Gdy domyślił się, że Belizariusz walczy, natychmiast wtargnął do Hipodromu przez wejście zwane Nekra. 53. W tej sytuacji buntownicy Hypacjusza atakowani z całą mocą z dwóch stron, zostali rozbici ${ }^{39}$.

Kulminacyjny moment całego powstania, czyli akcja Belizariusza. Zapewne nie byłaby możliwa, gdyby nie wspomniane wcześniej wojska najemne, w największym stopniu bucelariusze. Rysuje się tutaj zdecydowana przewaga wojsk najemnych nad gwardią pałacową, której cesarz nie mógł być pewny ${ }^{40}$. Wynika to jasno z fragmentu 45 dotyczącego żołnierzy pilnujących wejścia i czekających na rozwój wypadków ${ }^{41}$.

Ciekawe są natomiast zastosowany przez Prokopiusza zabieg retoryczny i epitety heroizujące samego Belizariusza, któremu autor poświęca praktycznie całość narracji, pomijając jednocześnie np. działania Narsesa ${ }^{42}$.

39 Prokopiusz z Cezarei, op. cit., przekł. D. BrodKa, s. 89-90.

${ }^{40}$ P. Filipczak, op. cit., s. 336.

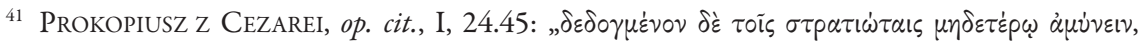

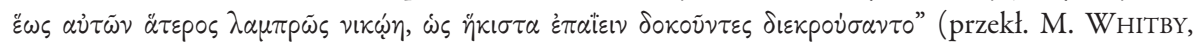
M. WhitBY); vide: Chronicon Paschale 284-628 AD, s. 123-124 (przyp. 363).

42 P. FilipCZAK, op. cit., s. 333. 
Z powodu zamkniętej bramy Belizariusz musiał przebić się przez spaloną część miasta i wejść na Hipodrom od północy, co spowodowało pewne trudności. W mieście, zupełnie jak na otwartym polu, nie można sobie pozwolić na walkę z dwóch stron, szczególnie mając ze sobą zapewne niewielki oddział. W ten sposób próbuje się tłumaczyć rzeź ludności z dnia 18 stycznia 532 r. Możemy jedynie przypuszczać, że gdyby gwardia pałacowa dochowała wierności i przepuściła Belizariusza, sytuacja mogłaby się potoczyć zupełnie inaczej.

Najemnicy jako „obcy” nie mieli skrupułów, zabijając mieszkańców stolicy, gdyż byli związani przysięgą i kontraktem z wodzem, któremu służyli. Natomiast żołnierze „rzymscy” zapewne mieli w tej kwestii większe opory. Przecież mieszkali w mieście, mieli tam swoje rodziny, posiadali własne „sympatie polityczne”. Z tego powodu wykorzystanie opłaconego, obojętnego dla polityki kraju wojska było rozsądniejsze w tamtej sytuacji.

Z drugiej strony nie możemy zapominać, że lud zgromadzony w Hipodromie składał się w większości ze zbuntowanej, niezadowolonej mieszanki ludności. Z pewnością nikt nie znalazł się tam przypadkiem, ale to nadal nie usprawiedliwia rzezi. Wojna zawsze rządziła i rządzi się swoimi prawami, a wydarzenia z 532 r. były dla ówczesnych jak wojna. Dlatego niech nie dziwi czytelnika fakt, że Prokopiusz w swojej narracji (frag. 51) ${ }^{43}$ snuje opis iście bohaterskiej bitwy, która de facto nie była bohaterska, nie była bitwą, a co za tym idzie - na pewno nie była sprawiedliwa.

Mimo że Prokopiusz wydaje się najbardziej wiarygodny, jeśli chodzi o opis wydarzeń z 18 stycznia, to pozostałe źródła przekazują nam dodatkowe informacje. Kronika Wielkanocna wspomina jeszcze o innych wydarzeniach, do jakich doszło przed rzezią na Hipodromie, a konkretnie tuż po koronacji Hypacjusza i jego przemieszczeniu się z Forum Konstantyna do kathysmy:

And there came too from Constantianae 250 young Greens, wearing breastplates. These young men came armed, supposing that they would be able to open up the Palace and lead him into it ${ }^{44}$.

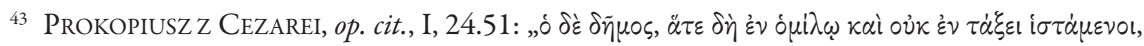

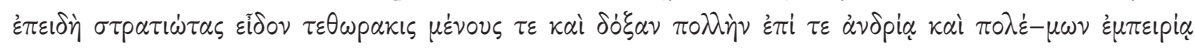

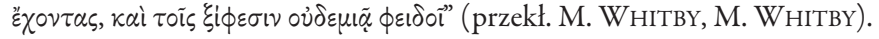

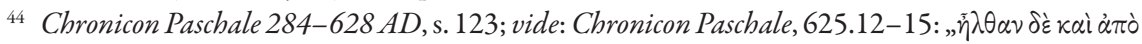

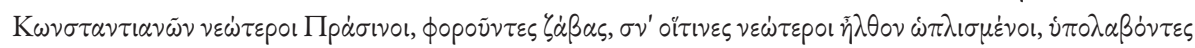

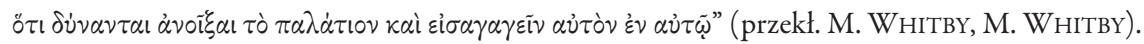


Michael Whitby przy okazji sugeruje tutaj, że bardziej od Błękitnych wspierali Hypacjusza Zieloni, co może wynikać z dawnych powiązań cesarza z tymi pierwszymi ${ }^{45}$. Być może rysuje nam się również pewien rozłam między stronnictwami - łącząc to z przeciąganiem Błękitnych na stronę Justyniana przez Narsesa. Niestety nie wiemy, co dokładnie stało się później, zapewne doszło do rozbicia oddziału Zielonych ${ }^{46}$.

Należy tutaj wspomnieć o pewnych różnicach w przekazie źródłowym Prokopiusza i Kroniki Wielkanocnej. Mimo że Kronika jest bardziej szczegółowa, ponieważ wspomina np. o synu Mundusa, który miał dowodzić skoordynowanym atakiem od południa, trzeba mieć na uwadze czas powstania źródła (ponad sto lat po opisywanych wydarzeniach). Prokopiusz, jak wiadomo, czerpał informacje od samego Belizariusza, co czyni ten przekaz, w moim przekonaniu, o wiele bardziej wiarygodnym od Kroniki Wielkanocnej.

W obliczu przedstawionych działań armii podczas powstania Nika swoistą konkluzją powinno być tutaj dość kontrowersyjne pytanie: Czy najemnicy ocalili tron Justyniana? To, że zrobili to Narses, Belizariusz i Mundus, nie ulega wątpliwości. W literaturze niedoceniana jest przez historyków mieszanina wszelkiej maści (barbarzyńskich) najemników i ich doniosła rola w stłumieniu powstania Nika.

\section{BIBLIOGRAFIA}

\section{Źródła drukowane}

Chronicon Paschale 284-628 AD, t. 7, przekł. M. Whitby, M. Whitby, Liverpool 1989, s. 114-127.

Chronicon Paschale, ed. L. Dindorfius, Corpus scriptorum historiae Byzantinae, t. 1, ed. E. Weber, Bonnae 1832.

Grzegorz z Nazjanzu, Epistulae - Saint Grégoire de Nazianze, Lettres, t. 2, ed. P. Gallay, Paryż 1967.

Grzegorz z Nazjanzu, Listy, przekł. J. Stahr, Poznań 1933.

45 Vide: ibidem, s. 123 (przyp. 362).

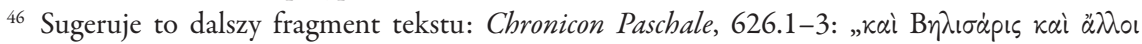

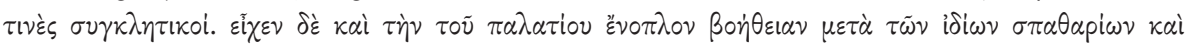

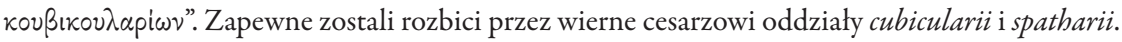


Ioannis Malalae chronographia, ed. L. Dindorfius, Corpus scriptorum historiae Byzantinae, ed. E. Weber, Bonnae 1831.

Prokopiusz z Cezarei, De bellis, ed. H. Jacobus, Procopii Caesariensis opera omnia, t. 1, ed. B.G. Teubner, Leipzig 1962.

Prokopiusz z Cezarei, De bellis, t. 1, przekł. D. Brodka, Kraków 2013.

\section{Opracowania}

Alivisatos H., Die Kirchliche Gesetzgebung des Kaisers Justinian I, Berlin 1913.

Bachrach B.S., Merovingian Mercenaries and Paid Soldiers in Imperial Perspective, [w:] Mercenaries and Paid Men: The Mercenary Identity in the Middle Ages, ed. J. France, Leiden-Boston 2008, s. 167-192.

Bury J.B., The Nika Riot, „The Journal of Hellenic Studies” 1997, t. 17, s. 92-119.

Cameron A, Circus Factions: Blues and Green at Rome and Byzantium, Oxford 1976.

Elton H., Army and Battle in the Age of Justinian (527-65), [w:] A Companion to the Roman Army, ed. P. Erdkamp, Oxford 2007, s. 532-550.

Evans J.A.S., The „Nika” Rebellion and the empress Theodora, „Byzantion” 1984, t. 54, nr 1, s. 380-382.

Filipczak P., Bunt Nika (532 r.), [w:] Konstantynopol - Nowy Rzym. Miasto i ludzie w okresie wczesnobizantyńskim, red. M.J. Leszka, T. Wolińska, Warszawa 2011, s. 327-336.

Gizewski Ch., Zur Normativität und Struktur der Verfassungsverbältinisse in der späteren römischen Kaiserzeit, München 1988.

Greatrex G., The Nika Riot: A Reppraisal, „The Journal of Hellenic Studies” 1997, t. 117, s. $60-86$.

Haldon J., Warfare, State and Society in Byzantine World, 565-1204, London 1999.

Leppin H., Justinian. Das christliche Experiment, Stuttgart 2011.

Liebeschuetz W., Warlords and Landlords, [w:] A Companion to the Roman Army, ed. P. Erdkamp, Oxford 2007, s. 479-495.

Mango C.A., The Brazen House: A Study of the Vestibule of the Imperial Palace of Constantinople, Kopenhaga 1959.

Nicasie M.J., Twilight of Empire: The Roman Army from the Reign of Diocletian until the Battle of Adrianople, Amsterdam 1998.

Remondon R., Soldats de Byzance d'après un papyrus trouvé à Edfou, Recherches de Papyrologie, t. 1, Paris 1961, s. 41-93.

Stownik grecko-polski, t. 1-4, red. Z. Abramowiczówna, Warszawa 1958.

Stickler T., The Foederati, [w:] A Companion to the Roman Army, ed. P. Erdkamp, Oxford 2007, s. 495-515.

Teall J.L., The Barbarians in Justinian's Armies, „Speculum” 1965, t. 40, nr 2, s. 294-322. 
Treadgold W., Byzantium and Its Army, 284-1081, Stanford 1995.

Whitby M., Recruitment in Roman Armies from Justinian to Heraclius (ca. 565-615), [w:] Late Antiquity on the Eve of Islam, ed. A. Cameron, London 2013, s. 277-341.

Whitby M., Army and Society in the Late Roman World: A Context for Decline?, [w:] A Companion to the Roman Army, ed. P. Erdkamp, Oxford 2007, s. 515-532.

Wolińska T., Kibice i nie tylko, czyli konstantynopolitańscy fakcjoniści, [w:] Konstantynopol - Nowy Rzym. Miasto i ludzie w okresie wczesnobizantyńskim, red. M.J. Leszka, T. Wolińska, Warszawa 2011, s. 226-234.

\section{Maciej Gdaniec}

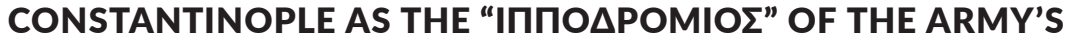 STRUGGLE AGAINST FACTIONISTS, REBELS AND CITIZENS DURING THE NIKA UPRISING OF 532}

Summary. This article presents the actions of the imperial army during the Nika revolt. The first use of the army, confirmed by sources, took place on 14, 17, 18 January 532. The first, source-confirmed, use of the army took place on 14 January. Fighting with the rebels under Belisarius continued until the evening and did not bring the expected results, the uprising continued and brought more and more destruction. On 17 January reinforcements arrived from the surrounding towns. As research shows, the mere appearance of a larger army in the city escalated tensions and paradoxically became the reason for its immediate use. The use of a larger force did not end the uprising and led to the greatest destruction since it began. The mercenaries under the command of Belisarius and Mundus proved to be the key foundation for maintaining Justinian the Great's power in January 532, as they proved loyal to their superiors and the emperor, compared to the troops of the imperial guard. The source giving the most information about the warfare during the Nika uprising turned out to be the Chronicon Paschale, which details the account of, among others, John Malalas. The account of Procopius of Caesarea seems to be useful only in interpreting the operations of 18 January.

Keywords: Nika uprising, circus factions, war, army, Belizarius 